\title{
The Phenomenon of Journalism-related Crimes Under the Circumstances of Hybrid War in Ukraine
}

Yevhen Pysmenskyy

\section{Abstract}

The article covers journalism-related crimes as a relatively distinct category of offences. The importance and purpose of isolating the concept of journalistic criminality under conditions of globalization in the modern theory of legal thought, the rapid development of the information society, and the embodied increase of the role of information and knowledge in human life are emphasized. Attention is paid to the factors affecting the dynamics and development of crimes in the area of professional activities of journalists, which primarily includes the environment of hybrid war. The destructive impact of the social consequences of journalistic crimes on society is evident in the case of Ukraine, which has suffered in the past and to this day experiences the latest information manifestations of hybrid war. The proposition to criminalize the intentional spreading of false information in the media by journalists is discussed. The reasons, basis and conditions for such criminalization are analysed. The existence of criminalization grounds for such an offence is substantiated in the article. However, conclusions are drawn on the inappropriateness of such criminalization due to its non-correspondence with certain conditions associated with difficulties in adjudication and with the problem of proving this type of behaviour. Other means of counteracting the deliberate dissemination of false information are considered.

\section{KEY WORDS:}

hybrid war, mass media, journalist, journalism-related crimes 


\section{Introduction}

The theoretical importance of the concept of hybrid war has been increasing within the modern political and legal discourse. The term is usually used to refer to a specific phenomenon that has become common in the world over the past decades. This phenomenon covers a complexity of classical methods of warfare, the exercise of military aggression (involving regular and irregular military formations), and new technologies, especially those related to the powerful information influence of the enemy and its allies.

Countries that face hybrid war often become vulnerable in various areas of social and political life. Special attention should be drawn, among other things, to the implementation of policies against crime, which, under such circumstances, are forced to undergo transformation due to the influence of some uncommon factors. The issue is about the appearance of new types of criminal behaviour and their proper legal analyses, about the issue of strengthening the repressive component of criminal law without violating its basic principles, and about the search for new and more effective or adequate criminal law measures.

It seems that the global scientific community should concentrate its efforts on finding successful ways to counter hybrid war by using the positive and negative experiences of those countries that have faced a similar phenomenon before. Ukraine is one of them: it has experienced all modern forms and methods of fighting a hybrid war with the Russian Federation. As is known, the active (open) phase of the war began in March 2014 with the annexation of Crimea, then continued with the seizure of parts of the territory of Donetsk and Luhansk regions. It is still going on.

The Ukrainian experience of combatting some of the modern manifestations of hybrid warfare might be interesting in different ways, but among those that are key is the emergence and development of new types of socially dangerous behaviour, and the acquisition of atypical features through such crimes. These include criminality in the area of journalism, which requires independent scientific review, thus allowing us 
to thoroughly analyse the status of a journalist within the focus of criminal law theory and practice.

In Ukraine, the status of a journalist is determined by Art. 1 of the Law of Ukraine on State Support to Mass Media and Social Protection of Journalists from 23 September 1997, according to which a journalist is a creative worker who professionally collects, receives, creates and engages in the preparation of information for the media, and performs editorial and official duties in the media (within the staff or on a freelance basis). A similar approach is reflected in Recommendation No. R (2000) 7, On the Right of Journalists not to Disclose their Sources of Information, adopted by the Committee of Ministers on 8 March 2000 at the 701st Meeting of Deputy Ministers, which states that the term "journalist" means any natural or legal person who is regularly or professionally involved in collecting and publicly disseminating information through any medium (CE 2000).

Thus, a journalist is someone who regularly works with information for the media, and whose main function is to work on collecting, processing and creating information for the media. The criminal law aspects of such activity are emphasized in this article.

In view of all the above, the purpose of this article is to study the phenomenon of crimes committed by journalists in the course of their professional activities, as well as crimes committed against journalists (when the journalist becomes a crime victim). One of the manifestations of this phenomenon is found in Ukraine, which remains in the hybrid war environment to this day.

The structure of the article allows primary consideration of the specifics in modern manifestations of hybrid war with an emphasis on its information component. Furthermore, the place of journalistic crime among other types of crime is demonstrated and its ability to be enforced under the influence of modern hybrid war factors is underlined. The following section refers to the criminal law limitations on the freedom of speech, followed by those issues surrounding a journalist as a potential crime perpetrator associated with the dissemination of knowingly false information. The last section accumulates key aspects of the discussed issues, forms conclusions and outlines potential directions for further research. 


\section{Hybrid war and its information component}

Recently, issues arising from hybrid war have been penetrating deeper into the scientific matter of political and legal studies. Study of its components, new types and means of warfare, and analysis of the gained experience in combating contemporary manifestations of hybrid warfare naturally form the agenda for many scientists in law and politics.

Understanding this phenomenon remains ambiguous in modern international law; however, experts agree that hybrid war is the newest type of war, in which the conflict involves various means of attack and defence going beyond the conventionally defined options and types of warfare. Researchers provide a list of possible real weapons that can be used by the parties. The definition of weapons in this case includes not only traditional types of weapon, but also model organizational and information types of weapons (Vlasiuk and Karman 2015: 232).

Political scientists also refer to the significance of the information component of hybrid war. They argue that the specifics of the armed conflict-the place and role of the military argument in politics-are largely determined by the degree of societal development and technological advancement. Simultaneously, the informative society creates essential forms of resistance, and such resistance does not necessarily have to be armed or open (Mahda 2014).

Hybrid war usually involves a combination of classic warfare and the use of irregular armed groups. According to the former security adviser to the UN and NATO General Frank van Kappen, "the state, which leads hybrid war, making a deal with non-state performers by the militants, local groups, organizations, the relationship is formally denied. These performers can do things that the state itself cannot do, because any state is obliged to follow the Geneva Convention and the Hague Convention on the laws of war on land, the agreements with other countries. All the dirty work can be shifted on shoulders of non-state groups" (CSAF 2014).

A bright example of such a hybrid course of war, in which a more militarily 
powerful aggressor state negotiates with non-government performers - groups of local people and militants with whom it denies any formal affiliation - is the Russian activity in Ukraine from 2014 to the present. At the beginning of the conflict, certain groups of Russian soldiers organized and coordinated armed volunteer detachments with the local population members in Eastern Ukraine, thus avoiding, to a certain point, direct entry of its troops over the Ukrainian border. Such a move allowed Russia to partially bypass international law related to warfare principles. Yevhen Mahda points out that hybrid warfare in Ukraine has not only revealed weak parts of the Ukrainian army and society, but has also articulated a new challenge to the world in general and to Eastern European countries in particular. The absence of open confrontation, the use of new tactics, misinformation, creating an atmosphere of panic and threats for a short period of time, and the use of human shields have all demonstrated the army's helplessness in this new type of war (Mahda 2014).

New information tactics in Ukraine related to the aggressive use of the media to manipulate public opinion have become particularly threatening. There is no doubt that appropriate conditions for further military confrontation and for masking external manifestations of aggression have been created with their help. According to Horbulin, there was not just enemy propaganda taking place in the Ukrainian scenario, but also a "war of meanings/senses" (the beginning of which could be related to the period of 2006-2007). The whole multiplicity of information channels has been involved to retransmit these senses. The main structural elements in such war are simulacra-images of something that does not exist in reality. The strategic goal of exploiting simulacra is to replace objective perceptions of target groups about the nature of conflict with the "information phantoms" that the aggressor needs (Horbulin 2014: 9).

For the time being, despite the fact that the Russian leadership has officially denied any involvement in the crimes committed in Ukraine, the intervention of the Russian Federation in Ukrainian politics, as well as its aggressive actions on Ukrainian territory, have received adequate legal assessment both at the highest levels of Ukrainian government as well as in the arenas of foreign and international policy. Positioning Russian armed forces in the territory of Ukraine in violation of national and international 
legal acts has been correctly recognized as partial occupation of the sovereign Ukrainian territory (UP 2014; UP 2015; PA 2015; UN 2014).

Russia uses many techniques in its hybrid war against Ukraine, but the major one is its information war (NR 2014). The roots of Russia's hybrid methods go back to the Soviet era, although the label is more recent. "Active measures", as hybrid warfare was called back then-such as spreading disinformation-was an integral part of Soviet foreign policy. Today, some of Russia's tactics are surprisingly similar, but the current information environment makes their use both more efficient and complex (NR 2017).

For example, "Russia's use of broadcasting tools for propaganda and psychological operations, part of a broader information campaign to support the Crimean annexation, caught both Ukraine and the West by surprise.... The information warfare campaign in Ukraine entailed concerted use of Russian state-controlled media" (Kofman and Rojansky 2015: 5).

The aggressor carried out the same activities in the separate districts of Donetsk and Luhansk. However, due to the difficulties of implementing the Crimean scenario in Donbass, the occupational forces resorted to stricter and more violent counterattacks in the pro-Ukrainian information sphere. Kidnappings and arrests of journalists, activists, streamers and bloggers took place in order to prevent the circulation of an alternative media picture from the occupied territories. In addition, like in Crimea, there were numerous examples of changing sides by employees of TV and radio companies that were seized by Russians. Later on, the same employees started working for the new media created by the Russian terrorist forces. Starting in summer 2014, the "Donetsk People's Republic" and "Luhansk People's Republic" (with the participation of Russian advisors) began converting the media space of the territories into an "information ghetto" where there was no chance of seeing or hearing an alternative perspective or receiving true coverage of events (Horbulin 2017a: 42).

As the researchers rightly point out, the use of misinformation could be the most effective means of hybrid warfare: "misinformation and propaganda are being used to complement the overall Russian-integrated approach to hybrid warfare. Russia uses the media, for example, Russia Today, Sputnik News, and members of the public sympathetic to Russia who write to 
newspapers, to spread misinformation in a highly persuasive and credible way. In the present conflict in Eastern Ukraine, Russia has effectively used the information sphere as an integral tool in its hybrid war against the people of Ukraine" (Bachmann and Paphiti 2016: 37); "past experience in Ukraine and theory evaluation indicate that the new-generation war includes multi-level efforts aimed at destabilizing the state functions and changing the internal order. The information space will provide a range of opportunities to reduce the opponent's potential, especially through the use of new technologies and information networking. A non-standard approach to the fight will be crucial in the new-generation wars" (Banasik 2016: 177).

Against this background, the European community pays more and more attention to the issues of negative information's influence in the context of contemporary hybrid war manifestations. The comprehensive analysis of the EU Strategic Communications with a View to Counteracting Propaganda (EP 2016), prepared by the European Union Institute for Security Studies and commissioned by the European Parliament, might serve as a relevant example here. Its authors emphasize that Russia and ISIL have been engaged in aggressive messaging and deceptive media campaigns, though using distinct narratives and aiming at different targets and audiences. Accordingly, the analysis draws attention to the strategic communications efforts undertaken by the EU, which are channelled into both defensive (react and respond) and offensive (probe and push) dimensions. Such understanding of the present context will hopefully allow an evaluation of what exact actions can be taken to improve the effectiveness of strategic communications within the EU itself (EP 2016).

\section{Journalism-related crimes as the new form of criminality}

The information-related component of a hybrid war, as demonstrated above, is implemented under a wide range of vectors, the media being one of them. Mass media and social networks are used extensively for the 
realization of political goals of the aggression which are usually achieved by regular war. Taking into account the necessity of preventing such hybrid war manifestations and effectively resisting them, there is a strong demand for the scientific exploration of journalistic work in the context of legal regulation.

The key concept of criminal law and criminology is the category of criminality. Today there is no doubt that criminality is a phenomenon attributable to any society. In its general form, it can be described as the commission of acts by a fraction of general public members that cause significant harm to a person, society, state or Commonwealth, thus constituting the most egregious type of human behaviour.

Legal features of criminality should be recognized as its important feature, and therefore crimes include only acts which are directly mentioned in criminal law and which can trigger penalties under this law. The theory of criminal law provides that, based on this feature, crimes are distinguished from other dangerous offences, particularly those that can potentially cause significant damage but are not identified as such in criminal law. Criminalization or decriminalization in law is the only legal means of changing the list of acts that are recognized as criminal.

As put by Yakov Gilinskiy, "criminality is a complex social phenomenon without 'natural' boundaries (as distinct from drug-addiction, drunkenness and suicide) and definable with the help of two multi-faceted criteria: 1) its danger or real harmfulness to society and 2 ) its designation in the penal code (nullum crimen sine lege) - there is no crime without its designation in the penal code" (Gilinskiy 2001: 74).

Criminality is extremely sensitive about social and political change and clearly reflects this. Changes in social relations under the influence of various factors (including the information component of hybrid war - the information war) can transform perceptions of criminality by affecting the emergence of new types of crime. As noted by Natalia Savinova, media space that is not regulated by law under conditions of an information society leads to a state of anomie in the latter: this is embodied in the change of social ideals and morals. When certain social groups no longer feel their involvement in the society, which brings about their exclusion, 
new social norms and values are denied by members of these groups, including declared patterns of behaviour; at the same time, their own (particularly an illegal pattern of) behaviour is put forward as a means to achieve social and individual goals (Savinova 2013: 209).

Professional, economic, environmental, organized, corrupt, recidivist, unintentional and other types of criminality are traditionally distinguished. Such classification helps, first of all, to specify the study of many issues; secondly, it is important for meeting practical goals in combating crime in general and its individual variations in particular (Danshyn 2009). Nowadays, taking into account the intensification of informational technologies development as inherent in a globalized society, there are even more reasons to believe in the emergence of a new type of criminality - that is, journalism-related criminality.

Firstly, journalistic crime may be crimes committed against journalists and their professional activities. Generally, any democratic state at the appropriate legal level protects the legitimate professional activities of journalists and their life, health and property, which may be harmed in connection with the implementation of such activities. Different means - including, in some cases, criminal ones - can be used for this purpose. Ukraine is among those countries whose Criminal Codes provide for liability for interference with the legitimate professional activities of journalists (Article 171). Thus, the following acts are recognized as criminal: 1) illegal taking of materials and technical means, prepared by a journalist in connection with his professional activity; 2) illegal denial of access to information by a journalist; 3) illicit prohibition on coverage of certain topics, display of individuals, criticism of the public official; 4) any other intentional interference with the legitimate professional activity of the journalist, 5) any form of influence on the journalist in order to prevent him from executing his professional duties or prosecution of a journalist based on his legitimate professional activities. In addition, due to the need to establish additional security guarantees for the legitimate professional activities of journalists, special criminal law provisions on liability for attacks on journalists' lives, health, freedom and property (Articles 345-1, 347-1, 348-1, 349-1 and part 2 of Article 375 of the Criminal Code of Ukraine) were introduced in 2015. These acknowledge not only that journalists may become victims of these crimes, but so too may their close relatives and family members. 
Pavlykivskyi notes that, unlike in post-Soviet countries, the legislation of European countries and the United States does not contain criminal law prohibition of violations of journalists' rights, which is, in his opinion, to some extent conditioned by the effectiveness of the regulatory norms in the area of ensuring freedom of speech and the activities of journalists in these countries. At the same time, the introduction of norms of criminal liability for interference with journalistic activities in Ukraine is broadly in line with the generally accepted principles of criminal law and principles of the criminalization of socially dangerous acts (Pavlykivskyi 2017: 6, 26).

Firstly, it is possible to concede that the legitimate professional activity of journalists gets protection at the highest legal level in Ukraine. The existing criminal law base is sufficient to protect journalists from almost all forms of influence, including obstruction of their activities. In recent years, there has been a trend towards expanding the range of criminalized acts connected with the obstruction of such activities, increasing the punishment for crimes against journalists and improving criminal legislation in this area. This does not exclude another component of the issue: the effectiveness of the relevant criminal law norms and the need to improve the mechanism of detection of this category of crimes, including their proof in court and a fair response to them from the state, because under the condition of Ukraine being in a state of hybrid war, the issue of exercising aggression against journalists is exacerbated.

Secondly, journalism-related criminality refers to journalists who, under appropriate circumstances, may be recognized as crime perpetrators in the area of their professional activities. This component of journalistic criminality is of higher interest, since it is much less studied and organized while relevant data on it remain mostly unstructured. In addition, the issue of crimes against journalists - i.e. those associated with the violation of their rights - is primarily the focus of the global legal discourse. As for the improper performance of professional functions by journalists, their abuse and unlawful acts of behaviour in the area of information relations, so far there is no adequate understanding of this complex criminal law phenomenon.

When describing journalists as potential crime perpetrators, one should take into account that journalistic activity consists of two types of action: that related to obtaining information (as well as its separate or related 
symptoms in the form of collection and creation) and that related to the usage of information (including its distribution and storage). There is no doubt that a journalist has the right to receive and use information in any way, except those prohibited by law and/or which violate the ethical principles of journalism. Some of these methods of unlawful procurement (use) of information by a journalist through their embodied high level of public danger can quite naturally create grounds for legal liability.

Therefore, it would make sense to divide all crimes that might be committed by a journalist in the course of his or her professional activities into the following two groups: 1) crimes committed when collecting, receiving and creating information; and 2) crimes committed when storing, distributing or otherwise using information.

The content of each of these groups will be further disclosed schematically. Based on the acts that are criminalized in Ukraine, subgroups of crimes that cover various forms of journalist violation of the legally regulated framework for collecting, receiving, creating, distributing, storing and otherwise using information will be pointed out.

\section{Crimes that can be committed by a journalist in the course of collecting, receiving and creating information under the Criminal Code of Ukraine}

These include:

1.1. Encroachment on the right to privacy: violation of home inviolability; violation of the secrecy of correspondence, telephone conversations, telegraph and other correspondence which is transmitted through means of communication or computer; violation of privacy.

1.2. Encroachment on the right to confidentiality: illegal gathering of information that constitutes commercial or banking secrecy with the purpose of using it.

1.3. Encroachment on the order of access to information: forgery of documents, seals, stamps and forms; sale or use of forged documents, seals, stamps; illegal use of special technical means to obtain information; unauthorized interference 
in the operation of electronic calculating machines (computers), automated systems, computer networks or telecommunication networks; illegal use of the symbols of Red Cross, Red Crescent and Red Crystal.

All the crimes mentioned are united by the fact that they are committed by a journalist with the purpose of obtaining access to certain information or facilitating such access. For example, these include cases when a journalist forges a specific document which gives him the right to obtain information that interests him.

\section{Crimes that can be committed by a journalist while storing, distributing or otherwise using information under the Criminal Code of Ukraine}

These include:

2.1. Interference with activities of a certain person or public body: interfering with activities of the law enforcement agent, state executive service employee; interference with activities of a statesman; interference with the judiciary; interference with activities of defence attorney or legal representative.

2.2. Disclosure or other use of a certain type of information: illegal disclosure of a medical secret; illegal use of information that constitutes a commercial or banking secret; disclosure of commercial or banking secrecy; illegal use of insider information.

2.3. Calls to commit crimes: public calls to commit a terrorist act; calls for actions that threaten public order; war propaganda; public calls for violent change or overthrow of the constitutional order or the seizure of state power; public calls for actions aimed at changing the territory or the state border of Ukraine.

2.4. Otherviolations associated with the use of information: treason; violation of citizenship equality based on race, nationality, religious beliefs, disability and other grounds; infringement of copyright and related rights; knowingly false report of a threat to the safety of citizens, destruction or damage of 
property; importation, manufacture or distribution of works that propagandize violence and cruelty, racial, national or religious intolerance and discrimination; desecration of state symbols; propaganda of Communist and National Socialist (Nazi) totalitarian regimes, extortion.

Current law enforcement practice does not yield many examples where a journalist would be prosecuted for these types of crime. One reason for this is the reluctance of law enforcement officers to enter into conflict with media representatives, since any accusation of a journalist committing an offence may end with a reciprocal allegation of violation of freedom of speech (there is no doubt that criminal prosecution as such is capable of having a "cooling effect" on a journalist). Sometimes this is true, since law enforcement pressure on a journalist may be related to his activity in the absence of necessary grounds for it. In other cases, though, a prominent statement about violation of freedom of speech can be nothing more than a cover to justify a criminal act committed by a journalist.

In Ukraine, the most well-known examples are the case against Gerus (Ukrainska pravda 2005) and the case against Kotsaba (Ipress 2016). We start with the most recent: the case against Guzhva. According to the report of the Prosecutor General's Office on 22 June 2017, the head of the internet resource Strana.UA and his accomplice were arrested on suspicion of extortion (Criminal Code of Ukraine Article 189: part 3). The pre-trial investigation revealed that the detained person (a journalist) demanded from the Member of Parliament of Ukraine money to the amount of $\$ 20,000$ for not disclosing information about his personal life and political activities in the media (PGO 2017).

A promising direction for current scientific studies is related to the expediency of criminalization of certain acts committed by a journalist as a special actor of crime, particularly that related to the dissemination of deliberately false information. As correctly mentioned in the legal literature,

"the newest challenge for those in crime control and prevention is to keep up with new innovations in crime and their impact. As well, policy makers must attempt to anticipate the risks and pitfalls that result from rapid change. This will require future 
research activities encompassing the effects of globalization, demography and its trends, technology, economics and social and organizational structures amongst others. Investment in all such research activities can yield significant benefits for the reduction of crime and the development of crime control in the future. We all have a role to play in preventing crime. If anything can be learned from the past, it is that appropriate expenditure on crime prevention planning can be more cost effective than seeking to solve the problem after it has become entrenched" (Graycar 2001).

\section{Criminal law limits on the freedom of speech}

One of the key issues arising in the context of journalistic crimes is the question of the line where freedom of expression ends and a certain criminal act begins. What limits should freedom of speech have in a democratic civilized society? Is it not true that establishing criminal liability for the commission of socially dangerous acts by a journalist in the course of his professional activities constitutes violation of freedom of speech?

The Ukrainian Constitution guarantees everyone the right to freedom of thought and speech, to free expression of one's views and beliefs. The right to freely collect, store, use and disseminate information orally, in writing or by any other means is granted to every person based on their own choice (UP 1996).

The relevant constitutional provision establishes the common civilizational rule that is completely consistent with the principles produced by international practice and clearly enshrined in many international legal documents.

At the same time, just like any other rule, it has a number of exceptions. We are talking here about the legally provided limitations on the exercise of freedom of speech. Indeed, exercise of the rights mentioned in Article 34 of the Constitution of Ukraine can be restricted by law for the benefit 
of national security, territorial integrity or public safety, for the prevention of disorders or crimes, for the protection of public health, protection of reputation or rights of other people, for preventing disclosure of information received in confidence, or for maintaining authority and impartiality of the judiciary. In the furtherance of this provision, Ukrainian legislation (along with that of most other countries) rightly prohibits the dissemination of information, which includes, among other parts, calls for the commission of certain socially dangerous acts, which conflicts with public morality norms, includes confidential information and establishes a set of measures of legal influence on people who violate such prohibitions.

Restrictions on the rights of an individual to collect, store, use and disseminate information are also provided in Part 2 of Article 29 of the Universal Declaration of Human Rights of 1948, according to which "in the exercise of his rights and freedoms, everyone shall be subject only to such limitations as are determined by law solely for the purpose of securing due recognition and respect for the rights and freedoms of others and of meeting the just requirements of morality, public order and the general welfare in a democratic society" (UDHR 1948).

Thus, the right to freedom of expression has certain limits in its implementation which are clearly defined at the level of legal regulations. Exercise of this right should be carried out in such a way that the rights, freedoms and lawful interests of other citizens and the rights and interests of legal entities should not be violated.

A special case of exercising the right to freedom of speech guaranteed by the Constitution of Ukraine is the professional activity of journalists. Such activity must have a lawful character. When collecting, creating and disseminating information, a journalist should act within the legally defined rules. He is obliged to adhere to the principles of information relations among which one should pay particular attention to the accuracy and completeness of information as well as the legitimacy of receipt, use, distribution, storage and protection (Article 5 of the Law of Ukraine on Information). These principles are an important foundation in the work of journalists on realizing the right to freedom of opinion and speech; they are designed to prevent abuse of this right and to the exclude the possibility of illegal and/or manipulative information influence. 
The aforementioned provision (to the principles of information relations), while having a general character is, however, of an imperative nature and imposes a duty on the journalist to use only true information in the course of his professional activity and not to abuse the rights given to him by the law. It is not accidental that breach of such principles by a journalist can form the basis for bringing him to legal (disciplinary, civil, administrative or criminal) liability.

Regarding the latter, the issue here is with the journalist committing the above mentioned offences related to unlawful means of receiving, using and disseminating information of certain content. In case of spreading false information - that is, fictional information (on events, things or facts that never occurred) or presented in a false manner (with distortion of information about certain events, occurrences or facts) - a journalist may be subjected for certain actions only to disciplinary liability or, in case of breach of civil rights and interests of a certain person, civil liability. A more severe form of legal liability for disseminating false information by a journalist is not prohibited by Ukrainian law.

The main question that arises in the absence of criminal liability for the dissemination of deliberately false information is related to the alleged contradiction between the criminalization of such actions and provisions on freedom of thought and speech under the Constitution of Ukraine and international legal acts. Realizing the complexity and ambiguity of the raised issue, I will try to assume the absence of such a contradiction. Part 1 of Article 34 of the Constitution of Ukraine sets the general rule for freedom of opinion and expression. There are quite justified exceptions from this rule related to the abuse of this right. Indeed, one of them is directly provided in part 3 of Article 34 of the Constitution of Ukraine and is implemented in a number of criminal statutes. Another is reflected in international law provisions (the previously mentioned part 2 of Article 29 of the Universal Declaration of Human Rights of 1948).

Therefore, there is reason to assert that dissemination by a journalist of deliberately false information does not contradict the mentioned constitutional and international legal provisions. Committing certain acts can naturally result in legal liability. 


\section{Journalists as potential perpetrators of crimes related to dissemination of deliberately false information: issue outline}

As previously established, the legitimacy of receipt, use, distribution, storage and protection is correctly recognized as one of the principles of information relations. Legal protection covers only such journalistic activity as is undertaken in accordance with statutory established requirements. However, illegal professional activities of journalists are not acceptable and, depending on the type of violation, require a proper response from both the socio-moral and legal aspects (i.e. within the implementation of all kinds of legal liability).?

At the same time, legal professionals are increasingly often addressing the fact that the current group of crimes that can be committed by a journalist in the course of his or her professional activity is not able to ensure the completeness of criminal law provisions in this area. After all, some acts of journalism conduct remain not punishable despite the inherent nature of their social danger. This is particularly the case with spreading deliberately false information by the mass media aimed at discrediting a natural person or entity in order to obtain illegal benefits (Busol 2015: 26), manipulating the consciousness of the population through media and information expansion (Savinova 2014: 111 ) and others. Some lawyers go even further, by offering to believe that there is a crime of "blatant lie, which causes serious harm", regardless of whether or not the person who disseminates false information is a professional journalist. It is reasonably emphasized that "if the function of criminal law is to prevent harm by deterring individuals from engaging in certain forms of conduct, then our laws would be remiss to not make lying subject to criminal sanction in certain egregious cases" (Druzin and Li 2011: 572-573).

In June of 2017, the head of the Security Service of Ukraine made a significant statement on the need to provide for an adequate legal 
treatment for all forms and methods of hybrid war in the Criminal Code of Ukraine. In his opinion, the adequate response to an enemy requires absolute joint actions, the integration of law enforcement and the force of public opinion as a weapon against Russian aggression in the information space (SCU 2017). There is no doubt that the deliberate dissemination of false information by journalists can be considered one of the manifestations of the hybrid war.

How justified is it to pose the question in such a way?

The current legal approach to the dissemination of deliberately false information by using mass media cannot indeed be considered sufficient; such actions are capable of causing significant damage to areas of criminal law protection. One argument is that neither disciplinary nor civil liability for the dissemination of false information by a journalist, as opposed to a criminal, can serve as an effective safeguard against serious violations in the area of information relations.

Considering all of the above, the issue of such acts' criminalization is quite interesting as a research perspective.

Any process of criminalization has to be conditioned by certain factors, among which the theory of criminal law names reasons, grounds and conditions of criminalization that should be applied systematically (Dudorov and Khavroniuk 2014: 65-67).

Having examined the likely range of reasons for criminalizing the dissemination of deliberately false information, one can prove the existence of at least two of them:

- The need to ensure the implementation of legal provisions that regulate the area of information relations (for instance, in Ukraine these are the laws on Information, on the Print Media (Press) in Ukraine and on Television and Radio) when determining journalists' obligation to disseminate accurate and objective information.

- The dynamics and prevalence of the mentioned act. As experts convincingly argue, spreading false information in Ukraine 
today is systemic, provided that there is still no effective measure of combating it (Savinova 2014: 100). Indeed, recent trends demonstrate that the abuse of rights by journalists, their deliberate use of false information that increasingly finds objective proof, has happened quite often. Against such a background, the issue of determining the mental approach of journalists to their own actions seems to be more complicated. Nevertheless, the nature of some information - its obvious and sometimes undeniable falsity — leads to the idea of high probability of intentional conduct.

The only reason for the criminalization of acts is in accordance with the appropriate level and nature of their social danger, which is characterized by the ability to cause significant damage to areas of criminal law protection (Dudorov and Khavroniuk 2014: 66).

With this in mind, dissemination of knowingly false information by a journalist, due to its nature, is first of all able in some cases to harm the interests of the society, the state, the commonwealth and even humanity. We are talking here about the intentional use of inaccurate data in mass media. Such actions can be committed in order to create a controlled impact on a particular group of people or humanity in general with a goal of inciting enmity and hatred, artificially creating a conflict situation or its escalation, and so on. As aptly noted by Ganna Yudkivska, a judge in the European Court of Human Rights, "false speech" can be no less dangerous than the classic "hate speech". The falsification of facts, even without explicit calls for violence, easily creates an atmosphere of hatred. The question of how modern mechanisms of human rights protection provide an adequate response to these challenges remains unanswered. Obviously, under the circumstances of today's media space, fake information is disseminated very easily (Yudkivska 2016) and therefore "open societies remain surprisingly susceptible to misinformation that instigates intimidation, discrimination and violence against vulnerable groups. Untruths doled out in hate campaigns find ready buyers even in a free marketplace of ideas" (Cherian 2016).

Modern Ukrainian practice covers some cases when a journalist uses inaccurate information, which ultimately leads to the breakdown of mobilization, disturbance of public order, spread of panic, loss of government or public institution authority, loss of business reputation and 
so on. However, journalistic crimes do not recognize borders and become international, thus creating a global problem. According to Victoriya Romanyuk, deputy chief editor of the StopFake project, ${ }^{2}$ the methods used in Russian propaganda are universal and can be employed against any opponent and any country. In 2015, the developers of this project analysed numerous obviously false reports in the context of the conflicts in Syria and Turkey, which allowed them to openly comment on the trends and universal approaches of the Russian propaganda machine (GU 2016). In Germany, the criminal case of Lisa F. attracted high publicity. On 16 January 2016, the Russian First Channel featured a story about a 13-year-old Russian-speaking resident of Berlin, Lisa, who had been allegedly kidnapped and raped by three men appearing to be migrants from the Middle East. The Berlin prosecutor's office, after conducting an investigation, concluded that the girl had never been raped or abducted. After that, a criminal case was filed against a journalist of the First Channel, Ivan Blagoy, who filmed a fake report on the "raped" 13-year-old Russianspeaking girl. Later, the criminal case against the journalist was closed due to a lack of evidence that Ivan Blagoy was aware that information about the commission of the crime was not true (DW 2016).

As for Ukraine, one of the most striking examples of coordinated media lies was the media report mentioning that Americans and Poles are fighting on the side of Ukrainian army. The fake topic of territorial claims on Ukraine from other neighbouring countries, including Poland, Romania and Hungary, has also intensified recently (GU 2016). Reports by Russian journalists on the crucifixion of a boy by Ukrainian soldiers in front of his mother and the supposed striking down of a Malaysian Boeing by a Ukrainian fighter in July 2014 have become almost textbook examples. Commenting on them, Taranenko correctly notes that during the coverage of Ukrainian news, journalists of the Russian media created false informational efforts aimed at exciting hatred towards the Ukrainian military and officials (Taranenko 2017).

One of the most dangerous facts is that the journalistic environment in Ukraine particularly has been influenced by the Russian special service.

2 This project has been created by professional journalists in order to counter the information war in Ukraine and is aimed at exposing outright false information about Ukraine, which is disseminated in the media. Nowadays «StopFake» has gone beyond an investigative journalism project and has turned into an international analytical platform which specializes in studying and recording instances of media influence and also remains an important center of media education in Ukraine. 
According to Roman Zaitsev, the executive director of Mirotvorets, the centre for the study of crimes against the national security of Ukraine, human security and international order, some Ukrainian media are used as instruments of propaganda in the hands of the enemy. They work directly or indirectly for the enemy, thus influencing the minds of Ukrainian citizens. However, he notes that the Ukrainian audience possesses much stronger immunity compared with the Russian (Faktyi 2016).

The discussed actions are also characterized by the creation of a real threat of causing substantial harm to public relations with regard to public order, public security, the authority of government agencies, the peace and security of humanity, and so on. We should not forget that the public danger of an act can vary under the influence of certain factors, hybrid warfare being one of them. Natalia Savinova's position draws attention in this respect. She proves that such circumstances fully demonstrate the need to identify the fact that the issue of criminalizing such acts as manipulation of the population's consciousness through the media and informational expansion has to be addressed as soon as possible (Savinova 2014: 111).

The criminalization of dissemination of deliberately false information complies with social and psychological features, according to which the act should be criminalized if such act is caused by its immorality or awareness of the population, based on the legal culture and sense of justice within the population. Almost all codes of ethics in journalism determine truthfulness and objectivity as the basis for professional virtues. According to experts on journalism ethics, a journalist must be sure of the veracity of the information he disseminates and be sure of the information source's trustworthiness. Journalists must be particularly vigilant in order not to harm anybody by unveiling incomplete or inaccurate information. Wilful distortion of facts, their biased selection, disseminating false information or obtaining material incentives from third parties for a biased publication constitute a gross violation of ethical standards (Ivanov and Serdiuk 2007: 135; Prystupenko 2008: 228-229; Vymětal et al. 2008).

As for the conditions of criminal law and the criminal procedural nature, then, first of all, the criminalization of dissemination by a journalist of deliberately false information has some ability to complicate the process 
of criminal law analyses in the area of establishing intentional fault as an essential element of the crime's mens rea and separating, based on this element, the instances of negligent dissemination of false information by a journalist. Secondly, the emergence of difficulties in proving the fact of committing such violation is quite possible, including proof of wilfulness when committing relevant acts. A striking example of this is the aforementioned criminal case of Lisa F., in which law enforcement agencies in Germany failed to prove the intention of disseminating inaccurate information by the journalist (unfortunately, the impossibility of proving this does not exclude the fact that the journalist could actually perceive the complete untrustworthiness of the disseminated information).

One of the perceived drawbacks of criminalization of the dissemination of knowingly false information by a journalist should be recognized as a currently existing threat of abuse by law enforcement agencies and by court of their positions when employing the discussed criminal law provision to pressure journalists, attack freedom of speech, and so on.

Thus, all necessary grounds for criminalizing the dissemination of knowingly false information by journalists are present, but not all preconditions. Accordingly, such a criminalization, in case of its potential implementation, may become very risky. The mentioned risks are perceived, and I am not, therefore, a supporter of implementing this scenario. At the same time, this does not mean that counteracting journalists' activities mentioned in this article is worthless. Obviously, this should be done in a way that does not involve a repressive character, which is inherent in criminal law.

Institutes of civil society, and the journalistic environment itself that has to demonstrate intolerance of malicious media practices, recognize and cover them, come to the foreground here. As for Ukraine, which remains in a state of hybrid war, it is equally important to formulate the appropriate information policy strategy at the state level, which would include a set of measures to detect fake news and its timely denial. In particular, the Ministry of Information Policy of Ukraine has recently created the internet project Information Troops of Ukraine, the slogan of which is "Do not let yourself be fooled - spread the truth!" With this resource, anyone who wishes can contribute to the search and refutation of false information in the context of the Ukrainian-Russian confrontation. To date a lot of 
We should not exclude the expediency of application and other nonstandard methods of protecting the country's information space, even though they can be perceived inconsistently. As the well-known Ukrainian researcher Horbulin rightly points out, in order to respond to hybrid aggression and protect its values, the state is forced to resort to the same grey methods of hybrid response. Unfortunately, very often those methods that the state should use to protect the values of society are contrary to the society's ideas about the correct system of state, the correct reality and their interrelation with the values of this society itself. Therefore, Ukraine today applies a whole arsenal of methods that seem to be undemocratic or ambiguous to an outsider. The prohibition of Russian channels and Russian social networks is a hybrid response to a hybrid threat. Horbulin proposes the following example to this observation. After the 11 September 2001 attacks, the Patriotic Act was enacted in the United States, a radical extension of the rights of intelligence and counterintelligence criticized by all human rights activists. The transformation of the United States into a dictatorship and the country of lost democratic freedoms has been drawn with vivid colours, especially by the Russian media. However, we still consider the United States one of the most demonstrative democracies, with a free political system. Having survived several transformations, this Act still exists, ensuring US security (Horbulin 2017b).

\section{Conclusion}

Modern manifestations of hybrid war serve as a powerful challenge for the countries that face them. One of the key features of hybridity is increasingly becoming the influence of negative information based on the implementation of mass media, the internet (including social networks) and other advanced computer technologies to achieve military and political objectives. The advantage of an informational and psychological impact on minds is becoming a prerequisite for the successful implementation of military goals, as has been convincingly proved by the current experience of Ukraine. 
One way of influencing negative information under the conditions of hybrid warfare is providing knowingly false information to the object of influence with the purpose of its disorientation. In Ukraine, such a method has gained wide application and was used long before the active phase of the military conflict. Media outlets have often been the source of misinformation with journalists being its carriers. Unfortunately, journalists are called to be true guarantors of the use of truthful information and to ensure the freedom of speech in any democratic society, and are able to use their status to the detriment of national and human security. The modern history of Ukrainian-Russian conflict convincingly proves this. It also clearly demonstrates the vulnerability of the state to the influence of active and aggressive information exercised in the course of professional journalism. Abuse of journalistic rights, a conscious disregard for the basic principles of information relations, violation of high ethical standards of journalism and legally regulated rules of receipt and use of information remain without legal response.

At the same time, it must be emphasized that the outlined specificity of hybrid warfare determines a special approach to journalists who deliberately participate in it through the media. The position of the state and society in respect of journalistic activities under such conditions may differ substantially from that established in many democratic countries of the world, where journalists carry out their mission beyond the context of inter-state conflict relations. Under any circumstances, it is impossible to unequivocally identify a journalist as a bearer of an information weapon, since the majority of journalists continue to perform their work in good faith, even within hybrid and open confrontation. On the other hand, to pretend that the phenomenon does not exist would seem a big mistake.

This article raises the question of isolating a separate category of criminality, which it is proposed be called offences in the area of professional journalistic activities. Such a type of criminality should be considered a system of criminal acts where a journalist can be either a victim or an offender.

It has been proved that offences in the area of professional journalistic activities constitute a combination of intentional acts committed by and against a journalist and are also related to his activities surrounding 
the collection, receipt, creation, dissemination, storage or other use of information. As a potential crime perpetrator, a journalist may be held criminally liable for the commission in the course of his professional activities of crimes related to: a) violation of the rules for collecting, receiving and creating information and $b$ ) distribution, storage and other use of information with certain content.

Instead, according to Ukrainian laws, under the conditions of information warfare, the criminal liability of a journalist is excluded for one of the most serious violations of professional journalistic activity, namely the dissemination of knowingly false information through mass media. Different aspects of the relevant question are discussed in the circle of expert lawyers. This article examines the possibility of establishing criminal liability for the commission of the said act, and concludes that despite the existence of reasons and grounds for its criminalization, it does not meet some of the conditions of criminalization (the issues of legal assessment and procedural proof of this type of behaviour), which in its complexity allows us to assert the inappropriateness of the adoption of such a legislative decision. Journalists' resistance of the dissemination of knowingly false information should be resolute, alongside the development of an appropriate strategy that will involve the employment of anti-fake technologies at both the state and civil society levels to protect their rights and interests. 


\section{B Bibliography}

Bachmann, S. and Paphiti, A., 2016. Russia's hybrid war and its implications for defence and security in the United Kingdom. South African Journal of Military Studies, 44(2): 28-67.

Banasik, M., 2016. Russia's hybrid war in theory and practice. Journal on Baltic Security, 2(1): 157-182.

Busol, O., 2015. Protydiia koruptsiinii zlochynnosti $\vee$ Ukraini $\vee$ konteksti suchasnoi antykoruptsiinoi stratehii: avtoreferat dysertatsii (doktor yurydychnykh nauk). Instytut derzhavy i prava imeni V.M. Koretskoho NAN Ukrainy.

Centre of Strategic Assessment and Forecasts (CSAF), 2014. Putin leads in Ukraine hybrid war-Major General retired Frank van Kappen. 28 April [online]. Available at: http://csef.ru/en/oborona-ibezopasnost/348/putin-vedet-na-ukraine-gibridnuyu-vojnu-5323 (Accessed 1 November 2016).

Cherian, G., 2016. The curious power of hate propaganda in open societies. [online]. Available at: http://theconversation.com/ the-curious-power-of-hate-propaganda-in-open-societies-67261 (Accessed 3 November 2016).

Council of Europe (CE), 2000. Recommendation No. R (2000) 7 of the Committee of Ministers to member states on the right of journalists not to disclose their sources of information. [online]. Available at: https://search.coe.int/cm/Pages/result_details. aspx? Objectld=09000016805e2fd2 (Accessed 3 July 2017).

Danshyn, I., 2009. Kryminolohiia: Zahalna ta Osoblyva chastyny: pidruchnyk. 2-he vyd. pererob. i dop. Kharkiv: Pravo.

Druzin, B. and Li, J., 2011. The criminalization of lying: under what circumstances, if any, should lies be made criminal?. Journal of Criminal Law \& Criminology, 101 (2): 529-573.

Dudorov, O. and Khavroniuk, M. eds., 2014. Kryminalne pravo: navchalnyi posibnyk. Kyiv: Vaite. 
DW, 2016. The Berlin prosecutor's office closed the case against the journalist of Channel One. 19 March [online]. Available at: http://p. dw.com/p/1IGHM (Accessed 4 July 2017).

EthicNet, 2008. International principles of professional ethics in journalism. [online]. Available at: http://ethicnet.uta.fi/international/international_ principles_of_professional_ethics_in_journalism (Accessed 1 November 2016).

European Parliament (EP), 2016. EU strategic communications. With a view to counteracting propaganda: in-depth analysis. [pdf]. Available at: http://www.europarl.europa.eu/RegData/etudes/ IDAN/2016/578008/EXPO_IDA(2016)578008_EN.pdf (Accessed 2 November 2016).

Faktyi, 2016. Rukovoditel "Mirotvortsa» Roman Zaytsev: «Nekotoryie SMI Ukrainyi prevratilis $v$ oruzhie propagandyi protivnika. 1 September [online]. Available at: http://fakty.ua/221705-rukovoditel-centramirotvorec-roman-zajcev-s-priskorbiem-konstatiruyu-chtonekotorye-smi-ukrainy-prevratilis-v-oruzhie-propagandy-protivnika (Accessed 2 November 2016).

Gilinskiy, Y., 2001. Concept of criminality in contemporary criminology. Papers of St. Petersburg's Juridical Institute of the General Prosecutor's Office of the Russian Federation, 3: 74-79.

Global Ukraine (GU), 2016. Project StopFake: interview with Victoriya Romanyuk. 18 March [online]. Available at: http://global-ukrainenews.org/en/2016/03/18/proekt-stopfake-interv-yu-viktoriyeyuromanyuk (Accessed 2 November 2016).

Graycar, A., 2001. New crimes or new responses. [pdf]. Available at: http://aic.gov.au/media_library/conferences/outlook4/graycar 1 . pdf [Accessed 3 November 2016].

Horbulin, V., 2014. «Hibrydna viina» yak kliuchovyi instrument rosiiskoi heostratehii revanshu. Stratehichni priorytety, 33(4): 5-12.

Horbulin, V., 2017a. The world hybrid war: Ukrainian forefront. Kharkiv: Folio. Horbulin, V., 2017b. «Tsinnosti suspilstva» i «hibrydnyi myn»: kryza modeli zakhystu. Dzerkalo tyzhnia, 25, [online]. Available at: https:// 
dt.va/internal/cinnosti-suspilstva-i-gibridniy-mir-kriza-modelizahistu-246525_html (Accessed 4 July 2017).

Ipress, 2016. Zhurnalista Kotsabu zasudyly do 3.5 rokiv viaznytsi. 12 May [online]. Available at: http://ipress.ua/news/zhurnalista_kotsabu_ zasudyly_do_35_rokiv_vyaznytsi_165363.html (Accessed 4 July 2017).

Ivanov, V. and Serdiuk, V., 2007. Zhurnalistska etyka: pidruchnyk. 2-he vyd., vypr. Kyiv: Vyshcha shkola.

Kofman, M. and Rojansky, M., 2015. A closer look at Russia's "hybrid war". Kennan Cable, 7, [pdf]. Available at: https://www.wilsoncenter.org/ sites/default/files/7-KENNAN\%20CABLE-ROJANSKY\%20KOFMAN.pdf (Accessed 2 July 2017).

Mahda, I., 2014. Hibrydna viina: sutnist ta struktura fenomenu. Mizhnarodni vidnosyny. Seriia «Politychni nauky», 4, [online]. Available at: http:// journals.iir.kiev.va (Accessed 8 November 2016).

NATO Review (NR), 2014. How information war can kill. 18 December [video]. Available at: http://www.nato.int/docu/review/2014/ Also-in-2014/Russia-Putin-Chernobyl-nuclear-reactor/ EN/index.htm (Accessed 3 July 2017).

NATO Review (NR), 2017. Hybrid influence-lessons from Finland. [online]. Available at: http://www.nato.int/docu/review/2017/Also-in-2017/ lessons-from-finland-influence-russia-policty-security/EN/index. htm?utm_source=facebook\&utm_medium=smc (Accessed 3 July 2017).

Parliamentary Assembly of the Council of Europe (PA), 2015. Resolution 2034 (2015): challenge, on substantive grounds, of the still unratified credentials of the delegation of the Russian Federation. 28 January [online]. Available at: http://zakon0.rada.gov.ua/laws/ show/12919 (Accessed 2 November 2016).

Pavlykivskyi, V., 2017. Kryminalno-pravove zabezpechennia svobody slova ta profesiinoi diialnosti zhurnalista: avtoreferat dysertatsii (doktor yurydychnykh nauk). Kharkivskyi natsionalnyi universytet vnutrishnikh sprav. 
Prosecutor General's Office of Ukraine (PGO), 2017. The head of the internet-publication 'Strana.UA' and his accomplice are arrested on suspicion of extortion. 23 June [online]. Available at: http://www. gp.gov.ua/va/news.html?_m=publications\&_t=rec\&id=210666\&fp=50 (Accessed 4 July 2017).

Prystupenko, T., 2008. Svoboda slova ta zhurnalistska etyka $\vee$ Ukraini. Uchenyie zapiski Tavricheskogo natsionalnogo universiteta imeni V.I. Vernadskogo. Seriya "Filologiya. Sotsialnaya kommunikatsiya», 21 (1): 219-230.

Savinova, N., 2013. Kryminalno-pravova polityka ta ubezpechennia informatsiinoho suspilstva v Ukraini. Kyiv - Kharkiv: Red. zhurn. «Pravo Ukrainy»), Pravo.

Savinova, N., 2014. Umysne poshyrennia nedostovirnoi informatsii ZMI: arhumenty na koryst potreby kryminalizatsii. Visnyk Asotsiatsii kryminalnoho prava Ukrainy, 2(3): 100-112. Available at: http:// nauka.nlu.edu.va/?page_id=249 (Accessed 7 November 2016).

Security Service of Ukraine (SCU), 2017. We call all patriots to stand shoulder-to-shoulder with us and share responsibility for the future of Ukrainian state - Hrytsak. 15 June [online]. Available at: https:// ssu.gov.ua/ua/news/8/category/21/view/3525\#sthash.XkkToCOx. dpbs (Accessed 4 July 2017).

Taranenko, M., 2017. Shchodo pytannia fenomena i sutnosti hibrydnoi viiny $\vee$ Ukraini. Jurnalul juridic national: teorie şi practică, [pdf]. Available at: http://www.jurnaluljuridic.in.ua/archive/2017/2/51. pdf (Accessed 4 July 2017).

Ukrainska pravda, 2005. Zhurnalista, yakyinapysav «paskvil»na Yushchenka, zasudyly na 3 roky. 21 July [online]. Available at: https://www. pravda.com.ua/news/2005/07/21/3011860 (Accessed 4 July 2017).

United Nations, 2014. General Assembly adopts resolution calling upon states not to recognize changes in status of Crimea region. 68th Session of the UN General Assembly, 27 March [online]. Available at: http://www.un.org/press/en/2014/gal1493.doc.htm (Accessed 1 November 2016). 
Universal Declaration of Human Rights (UDHR), 1948 (art. 29). [pdf]. Available at: http://www.ohchr.org/EN/UDHR/Documents/UDHR_ Translations/eng.pdf (Accessed 4 November 2016).

Verkhovna Rada (Parliament) of Ukraine (UP), 1996. The Constitution of Ukraine. 28 June [online]. Available at: http://zakon3.rada.gov.ua/ laws/show/254K/96-вр (Accessed 5 November 2016).

Verkhovna Rada (Parliament) of Ukraine (UP), 2014. Law on ensuring the rights and freedoms of citizens and on legal regime on the temporarily occupied territory of Ukraine. 15 April [online]. Available at: http://zakon3.rada.gov.va/laws/show/1207-18 (Accessed 2 November 2016).

Verkhovna Rada (Parliament) of Ukraine (UP), 2015. Act on the appeal of the Verkhovna Rada of Ukraine to the United Nations, European Parliament, Parliamentary Assembly of the Council of Europe, NATO Parliamentary Assembly, OSCE Parliamentary Assembly, GUAM Parliamentary Assembly and national parliaments of the countries of the world on the recognition of the Russian Federation as an aggressor state. 27 January [online]. Available at: http://zakon0. rada.gov.va/laws/show/129-19 (Accessed 2 November 2016).

Vlasiuk, V. and Karman, I., 2015. Deiaki osnovy poniattia «hibrydna viina» $\checkmark$ mizhnarodnomu pravi. Pravo i hromadianske suspilstvo, 10(1): 226-234.

Vymětal, S., Vitoušová, P., Čírtková, L. and Kloubek, M., 2008. Journalists and victims of crimes. Praha: THEMIS.

Yudkivska, A., 2016. "False speech" can be less dangerous than the classic "hate speech". 24 October [Facebook]. Available from: http:// www.facebook.com (Accessed 9 November 2016). 
Yevhen Pysmenskyy (ye.pysmenskyy@i.ua) is Associate Professor and head of the General Legal Courses Department of Luhansk State University of Internal Affairs named after E.O. Didorenko (Sievierodonetsk, Ukraine). He is a board member of several journals and author of more than 150 articles and publications. He received a Doctor of Legal Sciences degree from Taras Shevchenko National University of Kyiv in 2014. He is also a member of the Body of Consultants of the Supreme Court of Ukraine. He is the chairman of the Luhansk local branch of the NGO All-Ukrainian Association of Criminal Law. His teaching and academic activities mostly cover issues of criminal law. 